Article

\title{
Bartenders and Customers' Interactions. Influence on Sexual Assaults in Nightlife
}

\author{
Elena Duque $^{1}\left(\mathbb{D}\right.$, Javier Rodríguez-Conde ${ }^{2}$, Lídia Puigvert ${ }^{3, *}$ and Juan C. Peña-Axt ${ }^{4}$ \\ 1 Department of Theory and History of Education, University of Barcelona, 08035 Barcelona, Spain; \\ elenaduquesa@ub.edu \\ 2 Faculty of Law, University of Barcelona, 08034 Barcelona, Spain; javi.rodriguez.conde@gmail.com \\ 3 Department of Sociological Theory, University of Barcelona, 08034 Barcelona, Spain \\ 4 Instituto de Estudios Sociales y Humanísticos IDESH, Universidad Autónoma de Chile, \\ Santiago 7500912, Chile; juan.pena@uautonoma.cl \\ * Correspondence: lidia.puigvert@ub.edu
}

Received: 24 June 2020; Accepted: 27 July 2020; Published: 29 July 2020

\begin{abstract}
Nightlife establishments are meeting points for what the scientific literature has called "hookups" or "one-night stands" - that is, uncommitted sexual relationships that can sometimes result in unwanted or even violent experiences. The scientific literature has identified that sexual assault has usually been connected with alcohol abuse. Other studies have found that nightlife staff can be an active or passive party to violent events (sexual or otherwise), especially bouncers. However, less attention has been paid to bartenders, and their involvement in such events has not been analyzed in depth. This article presents an exploration of how some male bartenders interact with some male customers in the nightlife context to promote sexual relationships and how their interactions might influence possible sexual assault situations. The results of this study shed light on and help us to understand why sexual assault occurs in these spaces.
\end{abstract}

Keywords: nightlife; hookups; sexual assault; bartenders; interactions; risk factors

\section{Introduction}

Nightclubs have become central leisure venues, to the extent that they contribute to the creation of a night-time economy [1,2] and unique scenarios for the establishment of intimate affairs [3], whether stable relationships or casual encounters [4]. In particular, nightlife relationships usually develop into what the literature has characterized as "hookups" or "one-night stands" [5,6]-that is, uncommitted, sporadic sexual encounters involving different kinds of practices. Additionally, nightclubs may be critical spaces in which violent situations can occur, whether general violence or sexually motivated violence. In this framework, this paper attempts to contribute to the understanding of sexual assault in nightlife through an exploratory study about how the interactions between some bartenders and some customers can influence sexual assault in nightlife.

This exploratory study was developed in the framework of the Preventive Socialization of Gender Violence research line [7,8], developed by CREA, Community of Research in Excellence for All (https://crea.ub.edu). Working from an interdisciplinary perspective, CREA has conducted research about gender violence in universities [9,10], gender and cultural minorities [11,12], or masculinity models [13,14], among others. Many studies funded by European Commission and by National Agencies of Research have been conducted over the last 20 years on gender issues and have analyzed attractiveness models and gender violence and its prevention [15-18], including dating violence, violence in hookups [19], and consent in sexual relationships [10]. This study has been specifically linked to the Research Group on Education Overcoming Inequalities (GRESUD), coordinated by the 
University of Barcelona and focused on the analysis of inequalities and how to overcome them. One of the research lines mainly developed by this research group is the Preventive Socialization of Gender Violence mentioned above. Their members have conducted research to specifically understand the social dynamics influencing gender violence and how to prevent it. Taking into account this scientific background and the diversity of the researchers and disciplines, we carried out interviews with bartenders and customers and observations in nightclubs to analyze the elements that promote sexual assault and its prevention in depth.

\section{Background}

Although the violent events that occur in the nightlife context are diverse, a high volume of them are sexual assaults, which may involve physically, psychologically, or verbally abusive behaviors, mostly suffered by women [20-22]. Nightclubs can be the spaces in which these events occur or just the meeting point between the aggressor and the potential victim, which may occur later. In this sense, some authors [23] stress the need to shed light on the different forms that interpersonal aggression may take, especially considering the increasing emergence of non-traditional kinds of sexual relationships [6,24].

One factor that may contribute to the greater prominence of sexual abuse in nightlife relates to the environmental characteristics of the establishments. In their research, Buddie and Parks [25] note the lack of supervision or behavioral standards, as well as the existence of a pool table, while other research [22] highlights the presence of reserved areas for sex as an element that increases the chance of reporting sexual aggression. Additionally, the kind of customer who frequents a particular bar is a factor to consider since episodes of violence usually occur in bars with greater concentrations of large, homogeneous groups of young men [26] outnumbering women on the dance floor [27]. Other studies have identified "hotspots" for aggression, whether sexual or otherwise, and stress the high rate of sexual assaults associated with dancing [28].

Even though some studies have begun to analyze the occurrence of fights and violent events involving women in nightlife environments [29-31], the scientific literature on violence in nightclubs mainly emphasizes how this violence is often promoted and exerted by mostly heterosexual men [32]. In these studies, men who participate in such violent acts generally engage in fights, assaults, or other acts involving aggressive actions, which may ultimately lead to criminal behavior [33]. Different studies stress the connection between violence in nightlife environments and the predominance of a hegemonic model of masculinity [34,35]. Studies on masculinity models are useful for understanding the intersection between men's behaviors and violence, but it is important to emphasize that not all men who fit this hegemonic model of masculinity [36] are necessarily violent [37]. Scientific literature about new masculinities shows that there are different masculinity models that act in different ways in the face of violence. In the same vein, the research by Joanpere and Morla [38] shows that there are specific models of masculinity which exercise violence, while other masculinity models act against it.

One main risk factor for sexual assault identified in numerous studies of sexual assault in nightlife is alcohol intoxication. Various studies stress the sexual vulnerability associated with high levels of alcohol consumption, especially in young girls and women $[39,40]$, which may dull their perceptions of potentially unsafe situations, such as unprotected or unwanted sex [41]. Furthermore, in the eyes of potentially abusive men, alcohol consumption in women can be seen as a sign of increased sexual availability or promiscuity [42]. Men can use alcohol, along with a woman's style of dress or attractiveness, as an excuse to blame the victim $[40,43]$. In this sense, alcohol has been used as an excuse for violence, attributing the violent behavior as a direct consequence of being intoxicated by alcohol. However, the research by Noel and colleagues [44] shows that sexual aggression depends on the interaction of alcohol with men's other individual characteristics. In fact, a large majority of men participating in this study did not accept sexual aggression, even when they were intoxicated. Other studies $[45,46]$ show that assailants often target drunk women or women who appeared to be drunk or at least more intoxicated than them [46]. Becker and Tinkler [20] show how participants attribute responsibility more to alcohol, the setting, and the victim's behavior than to offenders. 
These kinds of situations are normalized, and it is believed that unwanted sexual encounters in nightlife are inevitable [21].

In the literature on sexual behavior in nightlife resorts or other holiday environments [42], some studies have analyzed the role of guides in "stirring up effervescence" [47] among young tourists and creating an atmosphere that lacks control. Sometimes they pressure customers to lose their inhibitions, generally through alcohol or drug consumption, in which the guides also often take part [48], which may lead to risky behaviors.

The role of bar and nightclub staff in the occurrence and prevention of violence and, more specifically, in events that involve groups of men engaging in fights has been widely analyzed. There is a body of literature reporting on the excessive use of violence by bouncers and other security staff in nightclubs [49] and also research [27] analyzing aggression between patrons and towards bouncers and barmaids. Additionally, research from Graham and colleagues [50] shows the very passive nature of security staff in relation to eventual acts of aggression towards women and sexual assault, in which they rarely intervene, especially when violence takes the form of harassment that is not strictly physical $[50,51]$. The cause of this lack of intervention is the predominance of a nightlife culture in which certain forms of sexual violence are widely accepted and standardized. In fact, in many cases, the same security staff may be reluctant to support victims because of their style of dress or because the victims are under the influence of alcohol [52]. Ultimately, security staff may even become the ones that perpetrate these sexual attacks $[50,53]$.

Less attention has been paid to the role of bartenders. There are few available studies that focus on analyzing bartenders' roles as providers of alcohol to intoxicated customers [54]. In their study, Toomey and her colleagues [55] analyze the negative effects of selling alcohol to already intoxicated patrons and how these sales can contribute to the creation of a more violent atmosphere in bars, but they do not explore its influence on sexual assault. Furthermore, other research has provided evidence of the effectiveness of training measures and protocols aimed at preparing bartenders to intervene in and prevent alcohol-related problems [56-58]. However, despite the central role of bartenders in the promotion or prevention of sexual assaults by male customers, this issue has not been sufficiently explored. To address this gap, this exploratory study analyzes how some male bartenders interact with some male customers in the nightlife context to promote sexual relationships and how their interactions might influence possible sexual assault situations [59].

\section{Materials and Methods}

This study was carried out in the framework of the Research Group on Education Overcoming Inequalities (GRESUD), specifically in the Preventive Socialization of Gender Violence research line. A communicative methodology [60] was used, which entails egalitarian dialogue with the end-users of the research to allow for an intersubjective creation of knowledge that enables a deeper and more accurate understanding of the studied reality and its transformative potential [61], therefore enabling a greater social impact [62]. Different research projects funded by the European Commission and by the National Agencies of Research have demonstrated the suitability of this methodology when researching gender, especially gender violence and its prevention. Data were collected in a communicative way by establishing a dialogue with participants to collect information and reflect together about sexual assault in nightlife. Using the collected data, we performed a communicative analysis to identify exclusionary and transformative elements. In this case, exclusionary elements are the interactions between bartenders and customers that can promote sexual assault in nightlife, and transformative elements are the interactions that can prevent it. For this article, we focused on exclusionary elements in the sense that we would like to understand the elements that can promote sexual assault in nightlife in depth. 


\subsection{Sample}

The fieldwork was conducted from November 2014 to November 2019. The data collection employed two techniques: observations and semistructured interviews.

For the interviews, the sample comprised 26 male participants aged 18-50 years, 18 bartenders, and 8 customers (See Table 1).

Table 1. Participants' ages.

\begin{tabular}{ccccc}
\hline Age & $\mathbf{1 8 - 3 0}$ & $\mathbf{3 1 - 4 0}$ & $\mathbf{4 1 - 5 0}$ & Total \\
\hline Bartenders & 9 & 8 & 1 & 18 \\
Customers & 4 & 3 & 1 & 8 \\
& $\mathbf{1 3}$ & $\mathbf{1 1}$ & $\mathbf{2}$ & $\mathbf{n}=\mathbf{2 6}$ \\
\hline
\end{tabular}

All the participants were white/Caucasian, and 25 of them were from urban areas and 1 was from a rural area. The interviews were carried out mainly in Barcelona (see Table 2), and people were selected via snowball sampling. Purposive sampling techniques were used to recruit participants from nightlife venues, such as lounges, discotheques, and nightclubs. All participants reported experiences that occurred in nightlife environments.

Table 2. Participants' locations.

\begin{tabular}{cccc}
\hline Place & Barcelona & Other Places & Total \\
\hline Bartenders & 11 & 7 & 18 \\
Customers & 7 & 1 & 8 \\
& $\mathbf{1 9}$ & 7 & $\mathbf{n}=\mathbf{2 6}$ \\
\hline
\end{tabular}

The profiles of the bars at which the bartenders had been working were diverse. Some of them were small pubs, and others were big and popular nightclubs in the city. We present a brief profile in Table 3 .

Table 3. Profile of bartenders' places of work.

\begin{tabular}{|c|c|c|c|c|c|c|c|c|}
\hline & \multicolumn{2}{|c|}{ Customer Profile } & \multicolumn{2}{|c|}{ Cost } & \multirow{2}{*}{$\begin{array}{c}\text { Dance Floor } \\
\text { Yes }\end{array}$} & \multicolumn{2}{|c|}{ Schedule } & \multirow{2}{*}{ Total } \\
\hline & $\begin{array}{c}\text { Mostly } \\
\text { Foreigners }\end{array}$ & $\begin{array}{l}\text { Mostly } \\
\text { Locals }\end{array}$ & $\begin{array}{c}\text { Free } \\
\text { Entrance }\end{array}$ & $\begin{array}{c}\text { Paid } \\
\text { Entrance }\end{array}$ & & $0-3 \mathrm{~h}$ & $0-6 \mathrm{~h}$ & \\
\hline \multicolumn{9}{|l|}{ Bartenders } \\
\hline Barcelona & 3 & 8 & 8 & 3 & 7 & 7 & 4 & 11 \\
\hline Bilbao & & 1 & 1 & & & 1 & & 1 \\
\hline $\begin{array}{l}\text { Catalan touristic } \\
\text { coast }\end{array}$ & 3 & & 3 & & 2 & 2 & 1 & 3 \\
\hline Granada & 1 & & & 1 & 1 & & 1 & 1 \\
\hline Tarragona & & 1 & 1 & & & 1 & & 1 \\
\hline Valencia & 1 & & 1 & & 1 & 1 & & 1 \\
\hline Total & 8 & 10 & 14 & 4 & 11 & 12 & 6 & $\mathrm{n}=\mathbf{1 8}$ \\
\hline
\end{tabular}

Among the eight customers, two of them usually visited big and popular nightclubs for drinking and dancing in Barcelona, as well as pubs prior to entering the nightclub. They usually visited some of the places where observations were made. Two others did not usually visit nightclubs; they usually visited bars and pubs with colleagues, most of which were not very touristic bars but were popular places for local people. The other four customers interviewed were more variable, as they sometimes visited big nightclubs and sometimes preferred small bars with mostly local customers. In summer, they usually visited more touristic places in Barcelona and in other parts of the Spanish coast.

The observations took place in Spain, mainly in Barcelona, one of the ten most visited cities in the world and known for its nocturnal environment. Additionally, observations were made in coastal 
towns with a high tourist influx in Catalonia and in Bilbao, Granada, Lleida, Madrid, Sevilla, Valencia, and Zaragoza. Specifically, 100 observations were made, and a minimum of 2 observations were made per month on Friday or Saturday nights during the aforementioned period, mainly in Barcelona. In summer and during the vacation period, the observation frequency increased, and observations were made in different towns and were not only focused on the weekend. The profile of the places observed is diverse, but all of them are popular and busy venues. We present a brief profile in Table 4 .

Table 4. Profile of bars and nightclubs observed.

\begin{tabular}{|c|c|c|c|c|c|c|c|c|}
\hline & \multicolumn{2}{|c|}{ Customer Profile } & \multicolumn{2}{|c|}{ Cost } & \multirow{2}{*}{$\begin{array}{c}\text { Dance Floor } \\
\text { Yes }\end{array}$} & \multicolumn{2}{|c|}{ Schedule } & \multirow[b]{2}{*}{$\begin{array}{l}\text { Total } \\
\text { Places }\end{array}$} \\
\hline & $\begin{array}{l}\text { Mostly } \\
\text { Foreigners }\end{array}$ & $\begin{array}{l}\text { Mostly } \\
\text { Locals }\end{array}$ & $\begin{array}{c}\text { Free } \\
\text { Entrance }\end{array}$ & $\begin{array}{c}\text { Paid } \\
\text { Entrance }\end{array}$ & & $0-3 \mathrm{~h}$ & $0-6 \mathrm{~h}$ & \\
\hline Barcelona & 5 & 5 & 5 & 5 & 9 & 1 & 5 & 10 \\
\hline Bilbao & & 2 & 1 & 1 & 1 & 1 & 1 & 2 \\
\hline $\begin{array}{l}\text { Catalan touristic } \\
\text { coast }\end{array}$ & 5 & & 4 & 1 & 5 & 4 & 1 & 5 \\
\hline Lleida & & 2 & 2 & & 2 & 2 & & 2 \\
\hline Madrid & 2 & 3 & 3 & 2 & & & & 5 \\
\hline Sevilla & 5 & & 4 & 1 & 2 & 3 & 2 & 5 \\
\hline Valencia & 2 & & 1 & 1 & 1 & 1 & 1 & 2 \\
\hline Zaragoza & & 2 & 2 & & 2 & 2 & & 2 \\
\hline Total: & 19 & 14 & 22 & 11 & 22 & 14 & 10 & $\mathrm{n}=33$ \\
\hline
\end{tabular}

\subsection{Procedure}

The general sequence of the interviews was as follows. First, to establish a proper rapport with the participants in an effort to address the topics under investigation, the researcher started the interviews with a general discussion about nightlife establishments as spaces for the initiation of eventual intimate sexual encounters. Next, the researcher presented the following thematic blocks related to the interactions between some bartenders and some customers that could contribute to the latter achieving their sexual goals, in order to explore the respondents' perceptions of the role played by some bartenders and some customers: (a) customers asking for help or looking for complicity from bartenders to establish sexual encounters; (b) bartenders' intervention to promote those sexual encounters; (c) specific strategies in nightlife environments, such as the use of alcohol, to achieve sexual aims; (d) the kinds of conversations between bartenders and customers about women that customers would like to hook up with, and (e) knowledge of sexual assault in nightlife. The researcher presented these thematic blocks so that bartenders and customers would speak freely about these issues. The researcher was orientating the interview by drawing on the previous literature review and exploring the elements that may intervene in the occurrence of sexual encounters in nightlife venues, such as the environmental characteristics of the establishments or the role played by alcohol, among others. Specific questions about sexual harassment and sexual assault in nightlife were asked. The conducted research addressed ethical considerations. The participants were informed of the aims and purposes of the research study and gave their consent to participate. Likewise, anonymity and confidentiality were guaranteed throughout the collection and analysis of the information and throughout the study's preparation.

The 100 observations were performed from an ethnographic perspective from November 2015 to November 2019 in natural settings-that is, observations occurred in the nightlife context with the researchers participating in those settings. The observations were communicative; therefore, they included both observing and establishing conversations with bartenders and customers to determine the meaning of the interactions. The observations were focused on the following: (a) the intention to establish sexual encounters, (b) the interactions between bartenders and customers to achieve their sexual goals, and (c) the elements participating in these interactions related to possible sexual abuse according to the literature (alcohol use and abuse, violence, social pressure, etc.). 


\section{Results}

In the following section, the main results of our study are presented, responding to the research question regarding how some male bartenders interact with some male customers in the nightlife context to promote sexual relationships and how their interactions might influence possible sexual assault situations.

The 26 informants described very similar situations. To avoid repetition, we selected the most significant quotations that represent the information that several of them expressed and provided during the data collection. We collected and used observational data to confirm that the selected quotations actually represent significant situations in the nightlife environment and the sexual encounters that occur in it.

\subsection{Sharing Information about Women Who Frequent Bars}

One of the strategies that some bartenders used to help some customers obtain sexual partners involved letting clients know if there were women in the bar that matched the profile of a potential sexual conquest. In this quotation, a bartender explains which women, in his eyes, are more accessible or more willing to have casual sex because they do not have a partner, among other criteria: "A friend who comes and says: "Hey, what girl do you think...?" Obviously, you know if this girl likes "being receptive", so to speak, or if she has a partner...Who can he go try something with? If he goes over there to that group, it is possible that some (women) will say "yes"" (B2). This kind of shared information relates not only to individual women, but entire groups of women can also be the targets of these comments and can be classified as a potential sexual conquest: "We know which girls would ... you know? Which girls would let themselves go". (B4).

Sometimes the bartenders tell their friends or regular customers about the presence of groups of women, advising them about which women have had more to drink. In the following quotation, one bartender reproduces the type of advice that he can give to a friend or an acquaintance in search of a "hookup": "That girl is a little bit tipsy. Try...try ... and see if you can! But don't go too far if she doesn't want to, OK?" (B1). As seen here, although the bartender warns the customer not to go "too far", at the same time, he is clearly inciting the male client to approach a woman who is a "little bit tipsy" to take advantage of her current level of intoxication.

The data from the observations reiterated these situations. It is typical to observe customers in a bar asking bartenders about women and talking about them while looking at them and even pointing at them with gestures.

Some bartenders have explained that this collusion between bartenders and customers usually constitutes a win-win situation. The bartender's assistance can be rewarded when, hours later, the bartender joins his "buddy" in his sexual endeavors; eventually, both of them end up having sex. Some bartenders and customers are aware that there is an implicit agreement between the two, along the lines of "one day for you, another day for me", or if the bar closes and the customer is with two women, the bartender knows that one woman will be for him. One of the customers interviewed explained this situation, and the intention of both the customer and the bartender was to take advantage of being on their "home ground" to get women.

"There was a guy in my gang who knew a bartender; he was an asshole who talked shit about women. What he wanted was to hook up with girls (...) [He was] a person who was in control, so he took advantage of the situation (... ) The bartender also took advantage...because they were buddies... so he [the bartender] also used to score afterwards." (C4)

This idea is also supported by other bartenders. In this quotation, a bartender explained that this is a usual situation between bartenders. It is not considered a favor to the customer but is a usual behavior for this informant: "The relationship between friends who want to get that ... I do not see it as a favor. I see it as normal thing between them; today it's my turn, and tomorrow I will be working and it will be your turn, if it's two bartenders. (...) If you help the one [the bartender who is not 
working this night] who is at the bar to meet girls and is flirting with two girls, then you may have the way paved for you." (B14).

When performing observations in the same location for a time, we observed some men that seemed to be alone in the local area and did not go out with other peers. A man that we observed during different nights was always "alone", frequently interacting with a specific bartender, having conversations about women and trying to establish sexual encounters with them. On occasions, this man went to the bar with more than one woman, including the bartender in the conversation, and all of them were drinking together.

In addition to sexual purposes, some bartenders can have other motivations for providing customers with a woman's information, which may include the potential economic gain derived from satisfying regular customers. In the following quotation, one bartender describes a situation in which the decision to help a client obtain a woman's personal phone number is based on whether the customer helps him earn money:

"There was a group of girls; he asked me for the phone number of one of them. He was a regular customer. Honestly, my reasons ... the boy, well, I knew him, but not that much, [only] since a month and a half ago. He came in often, just because he was working in that area; he was not a local. (... ) The girl, I didn't know her; she used to come on Saturdays from another place, and she was just another girl...Call me a bastard, but this is my bar, and I want that customer who comes every day and has three or four drinks to keep coming, and this girl who only comes every other Saturday and has a juice ... I don't care about her! (... ) I ended up giving her phone number to him (... ). We are not friends, but I'm interested in taking care of him [as a customer]." (B1)

\subsection{Increasing the Customer's Status}

Some bartenders help customers achieve their goals by creating a favorable environment in which particular events can occur. Bartenders thus may be the ones who approach a woman to introduce her to a buddy, or they can try to help their buddy to convince the woman to give him a chance. In our observations, we have seen how some bartenders take the lead in introducing customers when she sees a group of women "alone".

One strategy to promote sexual encounters developed by some customers looking for an alliance with bartenders was trying to increase their status by merely being familiar with the establishment's bartenders or manager. It is supposed that being friendly with the manager or bar employees can increase some men's appeal with some women. As this customer explains, "If thanks to you the waiters take better care of them, they feel special" (C6). In the following quotation, one of the participants explains why customers are able to improve their status if they are friends with the bar staff:

"People see you as someone who dominates the situation to some extent, someone who has access to booze, which in that moment is a very powerful weapon, as well as someone who has a means of getting something they want. You are someone who is positioned in a way that clearly attracts attention." (B2)

Another strategy to increase customers' perceived familiarity with the establishment is based on doing favors for women on the customers' behalf, such as turning the club's bar into an improvised cloakroom. The bartenders that we interviewed explained that some men use their acquaintance with the bartenders as a means of showing women that the bartenders will keep their bags or coats:

"Yes, the handbags, keeping the girls' handbags...I used to have a bar full of them, and it was curious because the guys brought me handbags, not the girls! And you say, "Ok, I'll keep them"." (B4)

This situation has been observed many times in the nightlife context. Some men started a conversation with some women by telling them not to be worried about their suitcases or bags because they know the bartenders and they can leave them in the bar, or they include this proposal during 
the first encounter. It is usual to see men, accompanied by women, leaving a woman's bag with the bartender in the bar during the night.

To ask for favors from the bartender is a common strategy. In the following quotation, a customer explains how he asks a bartender to allow a woman whom he wants to hook up with to enter the closed bar again to go to the bathroom. The bartender allows the woman to enter and says to her that, in exchange, she has to kiss the customer.

"We went out to smoke a cigarette, I wanted to hook up with her, but I didn't dare to... She said she wanted to go to the bathroom, but the bar was already closed. I told her not to worry, that I knew the bartenders and they would let her in. I went into the bar with her and said she wanted to go to the bathroom. The bartender told her that it had a price, a kiss on my mouth. She hesitated first but gave me the kiss." (C7)

\subsection{The Use of Alcohol to Achieve Sexual Goals}

All the respondents to the interviews agreed that using alcohol is one of the most effective strategies to increase the customers' chances of obtaining a sexual partner. In the words of one of the bartenders, "It's the power of booze!" (B13). In this regard, the bartenders stress that some customers tend to seek help from them to lead their potential targets to "lose control" due to high levels of alcohol consumption. First, customers usually ask bartenders to increase women's alcohol consumption by providing them with strong drinks or extra shots, usually taking advantage when women are distracted or go to the restroom. On other occasions, bartenders invite the targeted women to have additional alcoholic drinks, telling the women that it is an invitation from a particular man, as expressed here by one of the bartenders:

"I've been told, some people have told me, "put more in it [her drink]", when the girl is not looking, "Go on! Go on! Give her another shot!" I think they are aware that when someone is drunk, he/she loses control a little. See, it is a way-everyone has their strategies—and some follow them [these strategies]." (B2)

Extra shots appear to be the most recurrent and popular strategy to help men achieve their sexual goals in these settings. On one hand, shots are cheaper than drinks (which may be convenient if the customer is forced to pay for them). On the other hand, it is relatively easy for a bartender to offer customers a shot without causing a conflict with the establishment's manager since they do not have to charge customers for the shot. Importantly, some women feel "cool" when the bartender invites them to take a shot. According to our informants, these feelings mean that these women do not to reject the shot and thus fall prey to the strategy.

"Shots are the big issue; it is something that a bartender can do without having problems at work, and everybody is pretty receptive. They [customers] see it as a trick of seduction or as, "Look, what good vibes! They are inviting us [to take a shot]!" Normally, nobody rejects a shot." (B2)

Sometimes, some customers seek complicity by offering a large tip to the bartender to convince him to refill a particular woman's drink when she has not requested a refill. One waiter explains one real situation as follows:

"Customers seek complicity; they tell the bartender to invite them [the girls], but in that case, you couldn't invite them because the place is very controlled. So, they give him 5 euros and ask him to refill the drink of a certain girl. (... ) The bartender does it, and when the girl is freaking out, the bartender points to the man in question, so the bond is established." (B6)

In other cases, a customer explains that intoxicating women with alcohol is the initiative of the bartender, even if the customer did not ask for it. "I remember a night with some women. That the bartender was giving us shots of water and shots of tequila to them. he was getting them drunk for us. 
But it was the bartender's initiative ... we didn't ask him". (C8) However, in this case, the informant was talking about a bar that he usually visits and about a bartender who is not his friend, but he knows him from visiting the bar every weekend. Conversely, this bartender explains a very similar situation but claims that it was the customer who asked for water for him and alcohol for the woman, and he accepted:

"It has happened several times, a guy who asks for water for himself and alcohol for the girls. They're at a point where they're drunk, and if they drink any more, they'll go bad. Instead, they need to keep getting the girl drunk. I've done it, eh! I've given the boys a shot of water." (B15)

Although some of the interviewed bartenders said that they would rather not collaborate with customers who have tried to use alcohol to their advantage, we observed that sometimes it is actually difficult for them to stop serving drinks to customers, even if they understand that the customers or the women who are with them have consumed an excessive amount of alcohol.

In fact, this use of alcohol intoxication to achieve sexual goals is very common in the observations and in the conversations with bartenders and customers during them. Bartenders explain how some of them invite customers to take shots or take the initiative to facilitate the establishment of sexual encounters. Sometimes, a bartender does not have any specific interest in a customer establishing a sexual encounter, but they are interested in all the other elements of the sexual encounter that benefit the club, including increased alcohol consumption and spending and customers that return again if it is a place where they achieve their sexual goals, among others. In this situation, the bartender does not feel responsible about the sexual encounter produced or the existing risk factor for the intoxicated woman.

\subsection{Spite towards Women with Whom Some Men Want to Hook up}

One of the interactions identified between bartenders and customers is the conversations about the women with whom some men want to hook up. On some occasions, the woman's physical appearance seems to be the only reason for taking the first step with her. If the man thinks that the woman is not "pretty" enough and she could potentially lower his status, he will not interact with her. As expressed by one of the bartenders about his own opinion, "It depends on how needy you are...because if she is a slut but butt ugly, I will not even try (...) I prefer not to 'score' that night". (B5) However, in general, according to the information gathered, the process that leads to identifying potential conquests is not so much based on the woman's personal or physical features but on the man's assessment of their chances of success. In this sense, some men tend to opt for women who, in their eyes, are more accessible or "open" to having casual encounters in such a setting or women whom they consider to be an "easy target". When this is the sexual dynamic and the objective is "easy prey", the ways in which these men talk about women who have had one-night stands is generally disrespectful, using expressions such as "slut" to refer to these women and assuming that they will go to go to bed with them without any doubt. One bartender expressed this assessment/assumption in graphic terms: "It is mostly a mixture between 'she fucks for sure', 'she is so damn hot' and 'she is a slut', especially in the early stages" (B2). Moreover, we observed that it is also common for men who have this idea of women as "easy prey" to speak disrespectfully about the women with whom they have had sex, pretending to be ashamed or blaming alcohol for their behavior.

This situation can be aggravated in the case of foreign women, especially if they do not speak the local language. In the observations made during the summer vacation, this situation was more common. One of the customers who was interviewed explained how some men often target female tourists, taking advantage of their lack of knowledge of the local language to make fun of or to insult them directly:

"There was a German girl with a friend...So we went to the bar, and as we went in, the bartender and this other guy were clear on what to do. Full complicity! Additionally, because they were German and didn't understand Spanish, they spoke openly, "So what, you come with two more, huh?", and in front of the girls, as they didn't understand a word; they were insulting them and everything." (C5) 
Furthermore, these men not only put women down but also often treat them badly. Most of the interviewed bartenders agreed that these male customers looking for an easy target do not care about the women with whom they try to initiate a sexual encounter in a pub. Indeed, for these men, the woman is just one more "number" on their "list", and they do not care about any particular woman. One of the participants affirmed that these men do not care about and even despise the women with whom they interact and with whom they might have a sexual encounter: "No! They don't care about girls; girls are just a number to them, just another one ... Usually what they want is to have as many girls as they can get" (B14).

In this sense, the women with whom these men interact are just objects. In some bartenders' own words, these customers just "use" these women. In addition, the following quotation is from a bartender who noted that these kinds of behaviors are usually found in men who belong to the "night-time economy", so they know the rules of the game and how to apply them:

"They were not nice guys. They used to talk about girls as someone to use for one night (... ) Often the customers were people who worked in the night-time economy, people who owned bars.... they just go all out, right here and now. They were always the same [guys]." (B4)

The ways in which these men treat women can turn into public shaming in some cases. In this regard, a common aspect highlighted by the bartenders is how such men despise women, showing other men intimate photos and video recordings of these women without their consent. One of the bartenders described a situation in which an acquaintance showed him video recordings of the women with whom he had had sex, explaining the details of the encounters as follows (without the consent of the women):

"I used to get along with a friend who works at a nightclub; this guy was pretty cool, and even though currently I do not have much contact with him, I used to enjoy staying with him...He could spend three hours talking about girls...girls he had hooked up in the same week...he took his computer and began to show me videos of the girls he had fucked." (B14)

Although not all of these situations include sexual assault, sexual harassment and rape are not uncommon. Some male customers start harassing a woman by employing strategies such as getting the woman drunk to achieve their sexual goals, and then they force her to have sex with them. The bartenders explained that this type of harassment also occurs through the collaboration of bartenders and violent male customers. In some instances, bartenders participate in these episodes of sexual harassment and rape. One such episode was explained by one of the participants as follows:

"I've seen girls on the floor outside the club (...) there have been such cases. On one occasion, in another bar in which I have worked, there was a girl who was alone...There were three bartenders and one customer, and between the two bartenders and the customer...they went straight to her...They started serving shots of vodka until she got drunk...Then, one of the bartenders tried to come out with her...but she didn't want to...he called a taxi, grabbed her hand and put her in the taxi cab...The next day, two policemen came to the bar to ask questions because the girl reported a rape. He [the bartender] said he did nothing, but she eventually returned home, and the complaint was unsuccessful. The policemen said that "well, Nordic [girls] usually denounce ... "It was complicity between the two bartenders and the customer to see who would hook up with her." (B4)

\section{Discussion and Conclusions}

There are many sexual encounters in nightlife, and they are part of the existing sexual diversity in society. Sometimes, as the literature states [20-22], these uncommitted sexual encounters can become sexual assaults. This article sheds light on the risk factors that can turn these relationships into instances of sexual abuse by analyzing how some customers and bartenders interact to achieve these sexual encounters. In these interactions, there is significant diversity, and they are not always related to 
sexual violence. We highlighted the interactions between bartenders and customers that can promote sexual abuse.

Firstly, we identified the existence of camaraderie among some customers and some bartenders in order to establish sexual encounters in nightlife. In this framework, bartenders usually share inside information with customers about the "kind" of women who frequent the bar, emphasizing issues such as their apparent sexual availability or their drinking patterns. This kind of shared information relates not only to individual women but also to entire groups of women that can be the target of these comments and can be classified as potential sexual conquests. Additionally, some bartenders contribute by increasing the "status" of customers in women's eyes by allowing these customers to demonstrate their familiarity with the bar staff, providing favors such as keeping bags and coats for women and/or inviting them to have drinks.

According to the literature [39-41], there is significant evidence of how alcohol consumption and abuse are risk factors for sexual assault. In this sense, it is necessary to highlight that in the interviews, all of the respondents agreed that using alcohol is one of the most effective strategies to increase a man's chance of obtaining a sexual partner. Sometimes bartenders invite the targeted women to have additional alcoholic drinks, telling them that it is an invitation from a particular man. On other occasions, invitations to do shots are the usual tactic. The bartender can frequently invite the customer and women to do shots for free, and if the customer has to pay, it is cheaper than paying for a drink. Additionally, some women feel "cool" when the bartender invites them to take a shot; according to bartenders, in general, few people reject a shot.

Following the analysis of the interactions and the specific conversations between some bartenders and some customers about "potential conquests" identified as an "easy target", spiteful and disrespectful language towards women and talking about them as objects are common. In some cases, a woman's physical appearance is presented as the reason to establish a casual sexual encounter, but all the informants agreed that a huge number of men that interact with bartenders with the objective of achieving their sexual goals are generally looking for an "easy target" for their potential conquests and women that match the "easy prey" stereotype in their eyes. Some bartenders compare such men with hunters in search of prey and confirm that insults are also common and that these men use expressions such as "slut" to refer to these women. According to the literature [42,47,63], our results show that this situation can be aggravated in the case of unknown or foreign women. Furthermore, men who usually belong to the "night-time economy" talk about women as objects and "numbers of their list of conquests".

Although sexual casual encounters are very diverse and not obligatorily related to sexual assault, sexual harassment and rape are not uncommon. In previous research [19], the ways in which violent boys and men are very present in hook-ups were highlighted. In this article, we identify some elements that can promote these violent casual sexual encounters. Some men start harassing a woman and employ strategies such as getting her drunk to achieve their sexual goals and then force her to have sex with them.

In light of these findings, this study constitutes a pioneering contribution to the literature on casual encounters in the nightlife context $[5,6,64,65]$ and to the study of the situations and elements that may contribute to the occurrence of sexual abuse situations in such venues $[33,50,66]$. Furthermore, although prior studies have investigated the role of staff in relation to violent events occurring in nightlife venues $[49,51]$ or the behavior of male customers with high levels of alcohol consumption [56,58], our study explores a dimension that has not been previously analyzed: the interactions established between some bartenders and some customers and how these interactions can influence possible sexual assault situations.

Our conclusions agree with those of previous studies $[23,43]$ in terms of stressing the need to advance the available research on the potential forms of victimization that may result from new forms of intimate relations, with the aim of providing new evidence on the mechanisms that lead to the involvement of potential female victims in violent sexual relations. The results of this study 
have practical implications for educational intervention. Gender violence prevention with teenagers and young people is mainly oriented towards presenting information on future stable relationships and, on a few occasions, it is oriented towards casual sexual encounters. The elements identified in the interactions between some bartenders and customers in this article may serve as important discussion points for understanding sexual abuse in nightlife and contribute to its prevention. Future research on this topic could explore the interactions between bartenders and customers that can prevent potentially unwanted sexual advances in nightlife environments. On the other hand, female voices, from bartenders and customers, can be included in this further research, by analyzing how they identify or do not identify these interactions or, for example, how they interpret the alcohol invitations that they receive from some men or the offers to keep their bags behind the bar, among other elements. The inclusion of female voices can mainly contribute to identifying and analyzing how female bartenders act and interact in relation to the sexual assault in nightlife and how all women-bartenders and customers-can contribute to overcoming this. Additionally, casual sexual encounters and violence related to homosexual relationships in gay pubs can be studied. Finally, in order to extend this exploratory study and to analyze common and different trends in relation to sexual assault in nightlife, fieldwork in other European and non-European countries could be developed in further research.

Author Contributions: We declare that all authors have made substantial contributions. L.P. contributed to the conceptualization of the study under the research line of preventive socialization of gender violence. E.D. and J.R.-C. collected the data. J.C.P.-A., E.D., J.R.-C., and L.P. contributed to the formal analysis, discussion of the data, and drafted the manuscript, revised it, and made edits for important intellectual content. All authors approved the final manuscript. All authors have read and agreed to the published version of the manuscript.

Funding: This research received no external funding.

Conflicts of Interest: The authors declare no conflict of interest.

\section{References}

1. Hobbs, D.; Lister, S.; Hadfield, P.; Winlow, S.; Hall, S. Receiving shadows: Governance and liminality in the night-time economy1. Br. J. Sociol. 2000, 51, 701-717.

2. Levine, M.; Lowe, R.; Best, R.; Heim, D. "We police it ourselves": Group processes in the escalation and regulation of violence in the night-time economy. Eur. J. Soc. Psychol. 2012, 42, 924-932. [CrossRef]

3. Wells, S.; Tremblay, P.F.; Graham, K. Understanding Men's Aggression in Bars: Development of the Beliefs and Attitudes toward Male Alcohol-Related Aggression (BAMARA) Inventory. Alcohol. Clin. Exp. Res. 2013, 37, E260-E270. [CrossRef]

4. Gagné, N.O. Romance and sexuality in Japanese Latin dance clubs. Ethnography 2014, 15, 446-468. [CrossRef]

5. Eshbaugh, E.M.; Gute, G. Hookups and sexual regret among college women. J. Soc. Psychol. 2008, 148, 77-89. [CrossRef]

6. Garcia, J.R.; Reiber, C.; Massey, S.G.; Merriwether, A.M. Sexual Hookup Culture: A Review. Rev. Gen. Psychol. 2012, 16, 161-176. [CrossRef]

7. Gómez, J. Radical Love: A Revolution for the 21st Century; Peter Lang Inc.: Frankfurt am Main, Germany, 2015.

8. Valls, R.; Puigvert, L.; Duque, E. Gender violence among teenagers: Socialization and prevention. Violence Against Women 2008, 14, 759-785. [CrossRef]

9. Valls, R.; Puigvert, L.; Melgar, P.; Garcia Yeste, C. Breaking the Silence at Spanish Universities: Findings From the First Study of Violence Against Women on Campuses in Spain. Violence Against Women 2016, 22, 1519-1539. [CrossRef]

10. Vidu, A.; Tomás Martínez, G. The Affirmative "Yes". Sexual Offense Based on Consent. Masc. Soc. Chang. 2019, 8, 91-112. [CrossRef]

11. Garcia Yeste, C.; El Miri Zeguari, O.; Álvarez, P.; Morlà Folch, T. Muslim women wearing the niqab in Spain: Dialogues around discrimination, identity and freedom. Int. J. Intercult. Relat. 2020, 75, 95-105. [CrossRef]

12. Munte Pascual, A.; de Vicente, I.; Matulic, V.; Amador, J. The Invisible Feminist Action of Roma Families. Affilia 2020. [CrossRef] 
13. Flecha, R.; Puigvert, L.; Rios, O. The New Alternative Masculinities and the Overcoming of Gender Violence. Int. Multidiscip. J. Soc. Sci. 2013, 2, 88-113.

14. Portell, D.; Pulido, C. Communicative acts which promote new masculinities. Overcoming hegemonic masculinity in the workplace and the school. Masc. Soc. Chang. 2012, 1, 61-80.

15. Puigvert, L. Preventive Socialization of Gender Violence: Moving Forward Using the Communicative Methodology of Research. Qual. Inq. 2014, 20, 839-843. [CrossRef]

16. Racionero-Plaza, S.; Ugalde-Lujambio, L.; Puigvert, L.; Aiello, E. Reconstruction of Autobiographical Memories of Violent Sexual-Affective Relationships Through Scientific Reading on Love: A Psycho-Educational Intervention to Prevent Gender Violence. Front. Psychol. 2018, 9, 1996. [CrossRef]

17. Rios-González, O.; Peña Axt, J.C.; Sánchez, E.D.; De Botton Fernández, L. The Language of Ethics and Double Standards in the Affective and Sexual Socialization of Youth. Communicative Acts in the Family Environment as Protective or Risk Factors of Intimate Partner Violence. Front. Sociol. 2018, 3, 19. [CrossRef]

18. Torras-Gómez, E.; Puigvert, L.; Aiello, E.; Khalfaoui, A. Our Right to the Pleasure of Falling in Love. Front. Psychol. 2019, 10, 3068. [CrossRef] [PubMed]

19. Puigvert, L.; Gelsthorpe, L.; Soler-Gallart, M.; Flecha, R. Girls' perceptions of boys with violent attitudes and behaviours, and of sexual attraction. Palgrave Commun. 2019, 5, 1-12. [CrossRef]

20. Becker, S.; Tinkler, J. "Me getting plastered and her provoking my eyes" young people's attribution of blame for sexual aggression in public drinking spaces. Fem. Criminol. 2015, 10, 235-258. [CrossRef]

21. Kavanaugh, P.R. The continuum of sexual violence: Women's accounts of victimization in urban nightlife. Fem. Criminol. 2013, 8, 20-39. [CrossRef]

22. Sanchez, Z.M.; Santos, M.G.R.; Sanudo, A.; Carlini, C.M.; Martins, S.S. Sexual Aggression in Brazilian Nightclubs: Associations with Patron's Characteristics, Drug Use, and Environmental Factors. Arch. Sex. Behav. 2019, 48, 609-618. [CrossRef] [PubMed]

23. Klipfel, K.M.; Claxton, S.E.; van Dulmen, M.H.M. Interpersonal aggression victimization within casual sexual relationships and experiences. J. Interpers. Violence 2014, 29, 557-569. [CrossRef] [PubMed]

24. Monto, M.A.; Carey, A.G. A New Standard of Sexual Behavior? Are Claims Associated With the "Hookup Culture" Supported by General Social Survey Data? J. Sex. Res. 2014, 51, 605-615. [CrossRef]

25. Buddie, A.M.; Parks, K.A. The role of the bar context and social behaviors on women's risk for aggression. J. Interpers. Violence 2003, 18, 1378-1393. [CrossRef]

26. Marsh, P.; Kibby, K.F. Drinking and Public Disorder; Portman Group London: London, UK, 1992.

27. Geoffrion, S.; Sader, J.; Ouellet, F.; Boivin, R. Aggressive incidents inside a Montreal barroom involving patrons, barmaids and bouncers: A micro level examination of routine activity theory. Crime Sci. 2015, 4, 9. [CrossRef]

28. Graham, K.; Bernards, S.; Osgood, D.W.; Wells, S. “Hotspots” for aggression in licensed drinking venues. Drug Alcohol Rev. 2012, 31, 377-384. [CrossRef]

29. Forsyth, A.J.M.; Lennox, J.C. Gender differences in the choreography of alcohol-related violence: An observational study of aggression within licensed premises. J. Subst. Use 2010, 15, 75-88. [CrossRef]

30. Leonard, K.E.; Quigley, B.M.; Collins, R.L. Drinking, personality, and bar environmental characteristics as predictors of involvement in barroom aggression. Addict. Behav. 2003, 28, 1681-1700. [CrossRef]

31. Lowe, R.D.; Levine, M.; Best, R.M.; Heim, D. Bystander reaction to women fighting: Developing a theory of intervention. J. Interpers. Violence 2012, 27, 1802-1826. [CrossRef]

32. Schnitzer, S.; Bellis, M.A.; Anderson, Z.; Hughes, K.; Calafat, A.; Juan, M.; Kokkevi, A. Nightlife violence: A gender-specific view on risk factors for violence in nightlife settings: A cross-sectional study in nine European countries. J. Interpers. Violence 2010, 25, 1094-1112. [CrossRef]

33. Anderson, T.; Daly, K.; Rapp, L. Clubbing Masculinities and Crime: A Qualitative Study of Philadelphia Nightclub Scenes. Fem. Criminol. 2009, 4, 302-332. [CrossRef]

34. Quigley, B.M.; Corbett, A.B.; Tedeschi, J.T. Desired image of power, alcohol expectancies, and alcohol-related aggression. Psychol. Addict. Behav. 2002, 16, 318-324. [CrossRef]

35. Miller, P.; Wells, S.; Hobbs, R.; Zinkiewicz, L. Alcohol, masculinity, honour and male barroom aggression in an A ustralian sample. Drug Alcohol Rev. 2014, 33, 136-143. [CrossRef] [PubMed]

36. Connell, R.W.; Messerschmidt, J.W. Hegemonic Masculinity: Rethinking the Concept. Gend. Soc. 2005, 19, 829-859. [CrossRef]

37. Connell, R. Masculinity research and global change. Masc. Soc. Chang. 2012, 1, 4-18. 
38. Joanpere, M.; Morla, T. Nuevas masculinidades alternativas, la lucha con y por el feminismo en el contexto universitario. Masc. Cambio Soc. 2019, 8, 44-65.

39. Davis, K.C.; Stoner, S.A.; Norris, J.; George, W.H.; Masters, N.T. Women's awareness of and discomfort with sexual assault cues: Effects of alcohol consumption and relationship type. Violence Against Women 2009, 15, 1106-1125. [CrossRef]

40. Parks, K.A.; Scheidt, D.M. Male Bar Drinkers' Perspective on Female Bar Drinkers. Sex. Roles 2000, 43, 927-941. [CrossRef]

41. Macy, R.J.; Nurius, P.S.; Norris, J. Responding in their best interests: Contextualizing women's coping with acquaintance sexual aggression. Violence Against Women 2006, 12, 478-500. [CrossRef]

42. Calafat, A.; Hughes, K.; Blay, N.; Bellis, M.A.; Mendes, F.; Juan, M.; Lazarov, P.; Cibin, B.; Duch, M.A. Sexual harassment among young tourists visiting Mediterranean resorts. Arch. Sex. Behav. 2013, 42, 603-613. [CrossRef]

43. Koepke, S.; Eyssel, F.; Bohner, G. "She Deserved It" Effects of sexism norms, type of violence, and victim's pre-assault behavior on blame attributions toward female victims and approval of the aggressor's behavior. Violence Against Women 2014, 20, 446-464. [CrossRef]

44. Noel, N.E.; Maisto, S.A.; Johnson, J.D.; Jackson, L.A. The effects of alcohol and cue salience on young men's acceptance of sexual aggression. Addict. Behav. 2009, 34, 386-394. [CrossRef]

45. Homel, R.; Tomsen, S.; Thommeny, J. Public Drinking and Violence: Not Just an Alcohol Problem. J. Drug Issues 1992, 22, 679-697. [CrossRef]

46. Testa, M.; Parks, K.A. The role of women's alcohol consumption in sexual victimization. Aggress. Violent Behav. 1996, 1, 217-234. [CrossRef]

47. Tutenges, S. Stirring up effervescence: An ethnographic study of youth at a nightlife resort. Leis. Stud. 2013, 32, 233-248. [CrossRef]

48. Hughes, K.; Bellis, M.A.; Chaudry, M. Elevated substance use in casual labour at international nightlife resorts: A case control study. Int. J. Drug Policy 2004, 3, 211-213. [CrossRef]

49. Romain-Glassey, N.; Gut, M.; De Puy, J.; Mangin, P. When nightclub security agents assault clients more insight through a qualitative approach. J. Forensic Legal Med. 2014, 26, 46-49. [CrossRef]

50. Graham, K.; Bernards, S.; Wayne Osgood, D.; Abbey, A.; Parks, M.; Flynn, A.; Dumas, T.; Wells, S. “Blurred lines?" Sexual aggression and barroom culture. Alcohol. Clin. Exp. Res. 2014, 38, 1416-1424. [CrossRef]

51. Roberts, J.C. Bouncers and barroom aggression: A review of the research. Aggress. Violent Behav. 2009, 14, 59-68. [CrossRef]

52. De Crespigny, C. Young women, pubs and safety. Alcohol Young Pers. Violence 2001, 31-46.

53. Bacharach, S.B.; Bamberger, P.A.; McKinney, V.M. Harassing under the influence: The prevalence of male heavy drinking, the embeddedness of permissive workplace drinking norms, and the gender harassment of female coworkers. J. Occup. Health Psychol. 2007, 12, 232-250. [CrossRef] [PubMed]

54. Lenk, K.M.; Toomey, T.L.; Erickson, D.J. Propensity of alcohol establishments to sell to obviously intoxicated patrons. Alcohol. Clin. Exp. Res. 2006, 30, 1194-1199. [CrossRef] [PubMed]

55. Toomey, T.L.; Wagenaar, A.C.; Erickson, D.J.; Fletcher, L.A.; Patrek, W.; Lenk, K.M. Illegal alcohol sales to obviously intoxicated patrons at licensed establishments. Alcohol. Clin. Exp. Res. 2004, 28, 769-774. [CrossRef] [PubMed]

56. Johnsson, K.O.; Berglund, M. Education of key personnel in student pubs leads to a decrease in alcohol consumption among the patrons: A randomized controlled trial. Addiction 2003, 98, 627-633. [CrossRef]

57. Powers, R.A.; Leili, J. Bar Training for Active Bystanders: Evaluation of a Community-Based Bystander Intervention Program. Violence Against Women 2018, 24, 1614-1634. [CrossRef]

58. Toomey, T.L.; Erickson, D.J.; Lenk, K.M.; Kilian, G.R.; Perry, C.L.; Wagenaar, A.C. A randomized trial to evaluate a management training program to prevent illegal alcohol sales. Addiction 2008, 103, 405-413, discussion 414-5. [CrossRef]

59. Bartenders' Complicit Interactions with Womanizers: Ramón Flecha \& Lídia Puigvert: Free Download, Borrow, and Streaming: Internet Archive. Available online: https://archive.org/details/bartenders (accessed on 22 June 2020).

60. Gómez, A.; Puigvert, L.; Flecha, R. Critical Communicative Methodology: Informing Real Social Transformation Through Research. Qual. Inq. 2011, 17, 235-245. [CrossRef] 
61. Gómez, A.; Siles, G.; Tejedor, M. Contributing to social transformation through Communicative Research Methodology. Qual. Res. Educ. 2012, 1, 36-57.

62. Gomez, A.; Padrós, M.; Rios-Gonzalez, O. Reaching Social Impact through the Communicative Methodology. Researching With Rather than On Vulnerable Populations: The Roma Case. Frontiers 2019, 4, 9. [CrossRef]

63. Thomas, M. "What happens in Tenerife stays in Tenerife": Understanding women's sexual behaviour on holiday. Cult. Health Sex. 2005, 7, 571-584. [CrossRef]

64. Katz, J.; Schneider, M.E. Casual hook up sex during the first year of college: Prospective associations with attitudes about sex and love relationships. Arch. Sex. Behav. 2013, 42, 1451-1462. [CrossRef] [PubMed]

65. Lewis, M.A.; Atkins, D.C.; Blayney, J.A.; Dent, D.V.; Kaysen, D.L. What is hooking up? Examining definitions of hooking up in relation to behavior and normative perceptions. J. Sex. Res. 2013, 50, 757-766. [CrossRef] [PubMed]

66. Flack, W.F., Jr.; Daubman, K.A.; Caron, M.L.; Asadorian, J.A.; D'Aureli, N.R.; Gigliotti, S.N.; Hall, A.T.; Kiser, S.; Stine, E.R. Risk factors and consequences of unwanted sex among university students: Hooking up, alcohol, and stress response. J. Interpers. Violence 2007, 22, 139-157. [CrossRef] [PubMed]

(C) 2020 by the authors. Licensee MDPI, Basel, Switzerland. This article is an open access article distributed under the terms and conditions of the Creative Commons Attribution (CC BY) license (http://creativecommons.org/licenses/by/4.0/). 